\title{
Comprehensive overview: efficacy, tolerability, and cost-effectiveness of irbesartan
}

\author{
This article was published in the following Dove Press journal: \\ Vascular Health and Risk Management \\ 4 October 2013 \\ Number of times this article has been viewed
}

\section{Fotini Gialama \\ Nikos Maniadakis \\ Health Services Organisation and Management, National School of Public Health, Athens, Greece}

Correspondence: Nikos Maniadakis Health Services Organisation and Management, National School of Public Health, 196 Alexandras Avenue,

II 52 I Athens, Greece

$\mathrm{Tel}+302132010188$

Fax +30 21 06433980

Email nmaniadakis@esdy.edu.gr
Background: Hypertension represents a major health problem, affecting more than one billion adults worldwide. Irbesartan, an angiotensin II receptor blocker, is considered to be a highly effective treatment in the management of hypertension. The purpose of this review is to evaluate the efficacy, safety and tolerability profile, and cost-effectiveness of treatment with irbesartan in hypertension.

Methods: A review of the literature was conducted using the electronic PubMed and Cochrane Library databases and the Health Economic Evaluations Database of search terms relating to irbesartan efficacy, tolerability, and cost-effectiveness, and the results were utilized.

Results: Findings from the present analysis show that irbesartan either as monotherapy or in combination with other antihypertensive agents can achieve significant reductions in blood pressure, both systolic and diastolic, compared with alternative treatment options. Irbesartan was also found to have a renoprotective effect independent of its blood pressure-lowering in patients with type 2 diabetes and nephropathy. Furthermore, irbesartan demonstrated an excellent safety and tolerability profile, with either lower or equal adverse events compared with placebo and other alternative treatments. In terms of economic analyses, compared with other antihypertensive therapy alternatives, irbesartan was found to be a preferred option, that is less costly and more effective.

Conclusion: The evidence indicates that treating patients with hypertension alone or with type 2 diabetes and nephropathy using irbesartan can control hypertension, prolong life, and reduce costs in relation to existing alternatives.

Keywords: irbesartan, tolerability, safety, efficacy, cost-effectiveness, economic evaluation

\section{Introduction}

According to the World Health Organization, hypertension, defined as a systolic blood pressure $(\mathrm{BP}) \geq 140 \mathrm{mmHg}$ and/or diastolic $\mathrm{BP} \geq 90 \mathrm{mmHg}$, affects more than one billion adults worldwide. ${ }^{1}$ Hypertension is a major health problem and a prevalent risk factor for cardiovascular disease and related death. ${ }^{2}$ The prevalence of hypertension varies among European countries, the US, and Canada based on the results of a systematic review. Notably, the prevalence of hypertension for Europe was $44.2 \%$ compared with $27.8 \%$ in the US and $27.4 \%$ in Canada. ${ }^{3}$ The main factors that contribute to the development of high blood pressure can be attributed to social determinants such as age, income, educational level, unhealthy diet, tobacco consumption, physical inactivity, and excess of alcohol, and also to metabolic risk conditions such as obesity, diabetes, and raised blood lipids, and finally to other cardiovascular diseases, such as myocardial infarction, stroke, and heart failure, and finally to kidney disease. ${ }^{1}$ 
Antihypertensive therapy can effectively reduce BP, and therefore reduce the risk of coronary heart disease, heart failure, cerebrovascular disease, and may thus prevent mortality. Early on, management of hypertension was done with angiotensin-converting enzyme (ACE) inhibitors. ACE inhibitors interfere with the renin-angiotensin system by direct blockade of ACE, thereby reducing the circulating concentrations of angiotensin II. However, they do not block angiotensin II production completely, because angiotensin II can be generated by non-ACE pathways. Angiotensin II receptor antagonists/blockers represent a relative newer class of antihypertensive agents, developed to overcome some of the deficiencies of ACE inhibitors. ${ }^{4-6}$ Angiotensin II receptor blockers selectively block $\mathrm{AT}_{1}$ receptors, preventing binding of angiotensin II, inhibiting the renin angiotensin system, and lowering BP.

The antihypertensive efficacy of angiotensin II receptor antagonists in patients with mild-to-moderate hypertension has been evaluated and compared with ACE inhibitors, calcium antagonists, beta-blockers, and diuretics in several studies. ${ }^{7-20}$ Angiotensin II receptor blockers also slow the progression of renal disease associated with hypertension, have excellent tolerability, in fact similar to that of placebo, and are associated with a significantly lower incidence of adverse events.

Irbesartan belongs to this group of drugs and is approved for the treatment of hypertension, and is indicated for lowering BP either alone or in combination with other antihypertensive agents. It is a long-acting angiotensin II receptor blocker compared with some of the other drugs in this class, (eg, losartan and valsartan), characterized by high selectivity and significant blockade of the $\mathrm{AT}_{1}$ receptor. Numerous studies have evaluated the efficacy of irbesartan in reducing BP and establishing control in large patient populations with mild-to-moderate or severe hypertension. Irbesartan is also approved for the reduction of progression of renal disease in patients with type 2 diabetes and nephropathy. The objective of the present study was to review and synthesize the published evidence on the efficacy, tolerability, and cost-effectiveness of irbesartan.

\section{Search methods}

The electronic PubMed and Cochrane Library databases and the Health Economic Evaluations Database were searched using the term "irbesartan". All the resulting citations were screened to find out whether they were concerned with the efficacy, tolerability, and cost-effectiveness of irbesartan. This approach generated 41 studies evaluating irbesartan as monotherapy or as combination therapy in patients with hypertension only and/or type 2 diabetes and nephropathy and in patients with left ventricular hypertrophy, and also 15 cost-effectiveness studies. Studies were included in the review only if they were published in full papers and in the English language.

\section{Pharmacokinetics and pharmacodynamics}

Irbesartan has a rapid and almost complete absorption after oral administration, with maximum plasma concentration after administration $\left(\mathrm{C}_{\max }\right)$ occurring at approximately 20 minutes regardless of dose, ie, $50 \mathrm{mg}$ or $150 \mathrm{mg}$, and an average bioavailability of $60 \%-80 \%$, significantly higher than for losartan and valsartan, the oral bioavailability of which is approximately $33 \%$ and $23 \%$, respectively. ${ }^{21-23}$ Food does not affect the bioavailability of irbesartan in contrast with other angiotensin II receptor antagonists, such as losartan and valsartan, the bioavailability of which is shown to decrease or be slowed by food. ${ }^{4,24}$ In addition, pharmacokinetic parameters such as $\mathrm{C}_{\max }$, time required to reach $\mathrm{C}_{\max }\left(\mathrm{t}_{\max }\right)$, and area under the plasma concentration-time curve (AUC), increased in a dose-dependent, linear manner, after irbesartan doses of $150-600 \mathrm{mg}$ in healthy subjects. ${ }^{25}$ Analysis of trough concentrations of irbesartan indicated that a steady-state level of irbesartan was achieved within 3 days of single daily doses of $150 \mathrm{mg}, 300 \mathrm{mg}, 600 \mathrm{mg}$, and $900 \mathrm{mg}$. ${ }^{25}$ The volume of distribution of irbesartan at steady state is approximately 53-93 L, showing that irbesartan distributes into the extravascular space. ${ }^{22}$ Finally, irbesartan has the highest degree of plasma protein binding at approximately $96 \%$.

Irbesartan is metabolized via glucuronide conjugation and oxidation. After either oral or intravenous administration of irbesartan, more than $80 \%$ of the circulating plasma radioactivity is attributable to unmetabolized irbesartan. ${ }^{26}$ The primary circulating metabolite is the inactive irbesartan glucuronide conjugate (approximately 6\%). Remaining circulating metabolites do not add substantially to the pharmacologic activity of irbesartan. Irbesartan and its metabolites are excreted by both biliary and renal pathways. Following administration of an oral or intravenous dose of irbesartan, approximately $20 \%$ of the total radioactivity has been found to be recovered in the urine and the remainder in the feces. ${ }^{4,26,27}$ The elimination half-life of irbesartan averages 11-15 hours. In vitro studies showed that irbesartan is 
oxidized mainly via the cytochrome P450 isoenzyme 2C9, with negligible metabolism by $3 \mathrm{~A} 4 .^{28}$

Two studies in hypertensive patients have evaluated the effect of gender on irbesartan pharmacokinetics. Results showed that there were no significant gender effects on $\mathrm{C}_{\max }$, AUC, or the terminal elimination half-life of irbesartan. Even though women generally had higher $\mathrm{C}_{\max }, \mathrm{t}_{\max }$, and AUC values compared with men, these differences were not statistically significant or clinically relevant. ${ }^{29}$ Furthermore, no gender-related dosage adjustment was found to be necessary. ${ }^{30}$ The evaluation of age on irbesartan pharmacokinetics was similarly of no statistical significance. Healthy elderly male and female subjects (aged 65-80 years) had approximately $20 \%-25 \%$ higher AUC and $\mathrm{C}_{\max }$ values compared with healthy young (18-40 years) subjects. ${ }^{29,30}$ Concerning the effects of race on irbesartan pharmacokinetics, data from two single-dose pharmacokinetic studies showed that there were no statistically significant differences in $\mathrm{C}_{\text {max }}, \mathrm{AUC}$, or terminal elimination half-life between healthy black and healthy white normotensive subjects, although the mean values for AUC and terminal elimination halflife were $25 \%$ and $21 \%$ higher, respectively, in blacks. ${ }^{29,30}$ Studies in pediatric hypertensive patients are limited, but an open-label evaluation of the pharmacokinetics of irbesartan in children (aged 1-12 years) and adolescents (aged 13-16 years) showed that the plasma concentration-time profiles of irbesartan were comparable between children and adolescents..$^{29,31}$

Renal impairment, including end-stage renal disease requiring hemodialysis, did not influence the pharmacokinetics of irbesartan. ${ }^{32}$ In a open-label, parallel-group study comparing irbesartan pharmacokinetics between patients with hepatic cirrhosis and normotensive subjects, there were no statistically significant differences in $\mathrm{C}_{\max }, \mathrm{AUC}$, or terminal elimination half-life between these groups after single or multiple doses of irbesartan..$^{33}$ Finally, an evaluation of the pharmacokinetics of irbesartan in an open-label, randomized, two-way, crossover study showed no significant differences in mean values of $\mathrm{C}_{\max }$ between heart failure patients and control subjects after oral administration of irbesartan. ${ }^{34}$

Studies reveal that there are no significant pharmacokinetic interactions between irbesartan and hydrochlorothiazide (HCTZ), warfarin, nifedipine, or simvastatin. More specifically, in a randomized, double-blind, placebo-controlled study evaluating the effects of oral irbesartan administration on the steady-state pharmacodynamics and pharmacokinetics of warfarin, results showed no clinically important effect of irbesartan on the pharmacokinetics or pharmacodynamics of warfarin during concomitant administration. ${ }^{35}$ In an open-label crossover study assessing the effect of irbesartan on the pharmacokinetics of simvastatin in healthy subjects, irbesartan had no significant effect on the single-dose pharmacokinetics of total simvastatin acid. ${ }^{36}$ In a randomized, double-blind, placebo-controlled study comparing the pharmacokinetics of irbesartan as monotherapy and in combination with HCTZ in patients with mild-to-moderate hypertension, results showed that the pharmacokinetics of irbesartan were not affected by addition of HCTZ. ${ }^{37}$ Finally, irbesartan does not affect the pharmacokinetics and pharmacodynamics of nifedipine during concomitant administration, as shown in an open-label, crossover study in healthy subjects. ${ }^{38}$

In terms of pharmacodynamics, irbesartan is a potent, orally active, selective angiotensin II receptor type $\mathrm{AT}_{1}$ antagonist that blocks all actions of angiotensin II mediated by the $\mathrm{AT}_{1}$ receptor, regardless of the source or route of synthesis of angiotensin II. Irbesartan has the ability to inhibit the pressor response to exogenously administered angiotensin II in normotensive subjects and had a doserelated BP response as shown in several studies. ${ }^{39-41}$ Irbesartan inhibited the pressor response by up to $100 \%$ at peak after 4 hours of oral doses at 25-300 mg. ${ }^{40,41}$ Compared with losartan and valsartan in a double-blind, placebo-controlled, randomized, four-way crossover study, the degree and duration of angiotensin II receptor blockade induced by $150 \mathrm{mg}$ of irbesartan was significantly greater than with either $50 \mathrm{mg}$ of losartan or $80 \mathrm{mg}$ of valsartan. ${ }^{39}$ Furthermore, in studies evaluating its efficacy in hypertensive patients, chronic doses of up to $300 \mathrm{mg}$ had no effect of clinical importance on renal plasma flow, glomerular filtration rate, filtration fraction, or urinary excretion of sodium and potassium. ${ }^{42-44}$ Also, irbesartan in multiple doses in hypertensive patients does not affect serum uric acid during chronic administration, fasting triglycerides, total cholesterol, or fasting glucose concentrations. ${ }^{19}$

\section{Safety and tolerability}

Concerning the tolerability and safety of irbesartan, the results from placebo-controlled studies show that irbesartan treatment is well tolerated in patients with mild-tomoderate hypertension. The overall incidence of adverse events with irbesartan was comparable with that of placebo; the most common adverse events experienced with irbesartan were weakness, headaches, dizziness, fatigue, 
and musculoskeletal pain. ${ }^{16,45,46}$ There were no significant differences between irbesartan and enalapril in the overall incidence of adverse events. Adverse events were mild in general and occurred much less frequently in patients on irbesartan treatment. ${ }^{19,47-49}$ Major adverse reactions were headache, malaise, and dizziness. The incidence of cough with irbesartan and enalapril was $10 \%$ and $17 \%$, respectively. ${ }^{19}$ Results from another study concerning the incidence of drug-related cough though, show an even more significant difference between enalapril (18\%) and irbesartan (0\%). ${ }^{47}$ Comparing irbesartan with atenolol, the incidence of overall adverse events was similar with both treatments; however, irbesartan had no negative impact on heart rate in contrast with atenolol, which significantly lowered mean heart rate. The most common adverse events were fatigue, cold sensation, upper respiratory tract infection, dizziness, headache, somnolence, and musculoskeletal pain. ${ }^{20}$ Irbesartan compared with amlodipine and valsartan had a similar incidence of adverse events..$^{50,51}$

Finally, in two studies comparing irbesartan with losartan treatment, the percentage of patients experiencing adverse events was not significantly different between treatment groups. Also, there were no significant differences in mean change in heart rate from baseline at any time point. ${ }^{45,52}$ Early discontinuations because of adverse events were not considerably different between irbesartan $300 \mathrm{mg}$ and placebo. ${ }^{45}$ Concerning the safety and tolerability of a combination antihypertensive therapy, the addition of irbesartan to HCTZ, a thiazide-type diuretic, was in general well tolerated, as evident from several studies. Compared with placebo/ HCTZ, the frequency of adverse events reported within the first 24 hours after initiation of double-blind therapy was similar between the treatment groups. ${ }^{53}$ The most common adverse events were headache, fatigue, and nausea/vomiting, and had slightly higher incidences with an irbesartan/HCTZ combination compared with placebo/HCTZ. ${ }^{54}$ Long-term treatment with irbesartan/HCTZ did not have a negative effect on tolerability or safety. ${ }^{55}$

In the I-ADD (Irbesartan/Amlodipine in Hypertensive Patients Uncontrolled on Irbesartan 150 mg Monotherapy) study comparing the efficacy and safety profile of irbesartan/amlodipine combination therapy with irbesartan monotherapy, most treatment emergent adverse events were of mild or moderate intensity and only a few were considered severe. The most frequent adverse events were peripheral edema and edema leading to treatment discontinuation; however, these were associated with amlodipine treatment only and appeared at the beginning of study treatment. Mean values for potassium, sodium, and creatinine were similar on both fixed-dose combination and monotherapy treatments. ${ }^{56}$ The tolerability and safety profile was similar in the I-COMBINE (Irbesartan/Amlodipine in Hypertensive Patients Uncontrolled on Amlodipine $5 \mathrm{mg}$ Monotherapy) study between the irbesartan/amlodipine fixed-dose combination versus amlodipine monotherapy treatments. ${ }^{57}$ In COSIMA (the COmparative Study of Efficacy of Irbesartan/ HCTZ with Valsartan/HCTZ Using Home Blood Pressure Monitoring in the TreAtment of Mild-to-Moderate Hypertension), which compared irbesartan/HCTZ with valsartan/HCTZ, overall safety was similar in the two groups. ${ }^{58}$ The most common adverse events were infections, gastrointestinal disorders, and musculoskeletal disorders, mild-to-moderate in intensity, and in most cases not related to the study drug.

Finally, in a study comparing the efficacy of fixed combinations of irbesartan/HCTZ and losartan/HCTZ, no differences were observed between the two treatments with respect to adverse events or tolerability. The most common adverse events were cold symptoms and sore throat on the irbesartan/HCTZ regimen and headache in the losartan/HCTZ regimen. Also, for the irbesartan/HCTZ combination, heart rate was not considerably different from baseline based on 24-hour, daytime, and night-time pulse rate data, whereas with losartan/HCTZ heart rate was significant greater than baseline for the mean 24-hour and daytime values. ${ }^{59}$

\section{Efficacy in treatment of cardiovascular disease Efficacy of irbesartan monotherapy in hypertension}

Irbesartan is primarily indicated for the treatment of hypertension with proven efficacy in achieving significant BP reductions. There are several published studies (Table 1) demonstrating the efficacy of irbesartan for the treatment of patients with essential, mild-to-moderate and severe hypertension, both as monotherapy and in combination with HCTZ and other antihypertensive agents. The majority of the studies involved patients with seated diastolic BP of 95-110 mmHg, ${ }^{16,19,20,47,49-51,60,61}$ while others used limits of 95-100 mmHg, ${ }^{17,45} 90-110 \mathrm{mmHg},{ }^{46,48,62} 95-115 \mathrm{mmHg},{ }^{52}$ $90-120 \mathrm{mmHg},{ }^{63}$ or $115-130 \mathrm{mmHg} .{ }^{18}$ The primary efficacy outcome measure was reduction in trough seated BP in the 
majority of the included studies and reduction in trough 24-hour ambulatory BP in four studies. . $6,48,50,60$

The main exclusion criteria in general concerned patients with secondary or malignant hypertension, cardiovascular diseases such as stroke, myocardial infarction, and heart failure, renal failure or liver dysfunction, other concomitant diseases presenting safety hazards, and medications that could interface with the assessment of efficacy or safety.

Results from placebo-controlled studies show that irbesartan treatment, at doses ranging from $75 \mathrm{mg}$ to $300 \mathrm{mg}$, achieves a statistically significant reduction in both systolic and diastolic BP in patients with mild-tomoderate hypertension. ${ }^{16,17,46} \mathrm{BP}$ reductions were evident within 2 weeks with irbesartan treatment, although even greater reductions appeared in week 4 and thereafter, and were dose-related up to $300 \mathrm{mg}$ per day. In comparative studies, irbesartan $300 \mathrm{mg}$ in patients with mild-tomoderate hypertension resulted in greater reductions in trough seated diastolic BP and systolic BP compared with losartan. ${ }^{45,52}$ Further, irbesartan demonstrated significant greater reductions in mean systolic ambulatory BP, at trough, mean 24-hour diastolic and systolic ambulatory $\mathrm{BP}$, as well as office-measured diastolic BP and systolic BP compared with valsartan..$^{50}$ Compared with enalapril, atenolol, and amlodipine, irbesartan demonstrated comparable efficacy in reducing both diastolic and systolic blood pressure and normalized seated diastolic BP at dosages up to $300 \mathrm{mg} \cdot{ }^{19,20,47-49,51}$ Finally, in a study by Oparil et al, irbesartan compared with the newest angiotensin II antagonist, olmesartan, showed similar reductions in ambulatory BP, as well as in seated systolic BP. However olmesartan achieved significant greater reductions in seated diastolic BP than irbesartan. ${ }^{63}$

\section{Efficacy of irbesartan in combination therapy for hypertension}

In many cases, hypertensive patients require the addition of a second drug to achieve adequate BP control. The literature search identified several studies evaluating the efficacy of irbesartan combined with HCTZ for the treatment of patients with mild-to-moderate or severe hypertension. Primary efficacy outcomes and exclusion criteria for patients were similar to the ones mentioned above. Patients' seated diastolic BP in the majority of the studies was $95-110 \mathrm{mmHg},{ }^{53-58,64-74}$ while others used limits of $70-109 \mathrm{mmHg},{ }^{75} 95-114 \mathrm{mmHg},{ }^{59}$ or $100-109$ mmHg. $^{76}$
Results from three placebo-controlled studies showed that reductions from baseline trough seated diastolic BP and systolic BP with irbesartan/HCTZ combination were greater compared with placebo/HCTZ. Results were obvious within 2 weeks of treatment with irbesartan/HCTZ. ${ }^{53-55}$ Similarly, the INCLUSIVE (IrbesartaN/HCTZ bLood pressUre reductionS in dIVErse patient populations) trial as well as subgroup analyses of this trial showed that irbesartan/HCTZ combination therapy leads to substantial reductions in both systolic BP (in more than $75 \%$ of patients uncontrolled on monotherapy) and diastolic BP. ${ }^{66,74,75}$

In comparative studies, the fixed combination of irbesartan/HCTZ had a superior BP-lowering effect compared with valsartan/HCTZ, and there was a significant difference in adjusted mean changes from baseline 24-hour ambulatory diastolic BP and systolic BP compared with losartan/ HCTZ. ${ }^{58,59}$ Further, in patients with severe hypertension (ie, seated diastolic $\mathrm{BP} \geq 110 \mathrm{mmHg}$ ), irbesartan/HCTZ resulted in greater and more rapid reductions in BP, compared with irbesartan $150 \mathrm{mg}$ or $300 \mathrm{mg}$ and HCTZ $12.5 \mathrm{mg}$ or $25 \mathrm{mg}$ monotherapies.$^{68-70,73}$ Finally, results from the I-ADD and the I-COMBINE studies, which evaluated the efficacy of irbesartan/amlodipine combination therapy, suggest greater efficacy with the fixed-dose combination of irbesartan $150 \mathrm{mg} /$ amlodipine $5 \mathrm{mg}$ over amlodipine $5 \mathrm{mg}$ and irbesartan $150 \mathrm{mg}$ monotherapies. ${ }^{56,57}$

\section{Efficacy in hypertensive patients with type 2 diabetes and nephropathy}

Irbesartan is also indicated for the treatment of renal disease in adult hypertensive patients with type 2 diabetes mellitus. Results from the IDNT (Irbesartan in Diabetic Nephropathy Trial) and IRMA (Irbesartan in Patients with Type 2 Diabetes and Microalbuminuria) trials show that irbesartan was associated with better renal outcomes compared with amlodipine, placebo, and other antihypertensive agents. Further, irbesartan provided a significantly slower increase in serum creatinine concentration and decrease in creatinine clearance and reduced the rate of progression to albuminuria (by $38 \%$ and $24 \%$ with irbesartan $300 \mathrm{mg}$ and $150 \mathrm{mg}$, respectively)..$^{77,78}$

Irbesartan was also found to reduce microalbuminuria both in diabetic and nondiabetic patients, resulting in an increase in the percentage of patients with normoalbuminuria from $17.1 \%$ at baseline to $40.9 \%$ and in a decrease in patients with microalbuminuria from $49.2 \%$ to $23.2 \% .{ }^{79,80}$ Finally, irbesartan was found to reduce significantly the albumin excretion rate in 
Table I Trial studies in hypertension: methodologic characteristics, results, and conclusions

\begin{tabular}{llll}
\hline References & Study design & Comparator & Population
\end{tabular}

\section{Monotherapy}

Fogari et al ${ }^{16}$

Larochelle et al

Kassler-Taub et $\mathrm{al}^{45}$

Pool et al ${ }^{17}$

Oparil et al ${ }^{52}$

Stumpe et $\mathrm{a}^{20}$

Mimran et al ${ }^{19}$

Lacourciere et $\mathrm{al}^{49}$

Chiou et al ${ }^{47}$

Oparil et $\mathrm{al}^{63}$

Coca et al ${ }^{48}$

Mancia et al ${ }^{50}$

Hwang and $\mathrm{Lu}^{60}$

Morales-Olivas

et $\mathrm{al}^{46}$

Neutel et al ${ }^{51}$

Coronel et $\mathrm{a}^{62}$
Multicenter, randomized,

double-blind, placebo-controlled

Multicenter, randomized, double-blind, placebo-controlled

Randomized, double-blind

Multicenter, randomized, double-blind, placebo-controlled

Multicenter, randomized, double-blind, Losartan elective-titration

Multicenter, randomized, double-blind

Multicenter, randomized, double-blind

Multicenter, randomized, double-blind

Multicenter, double-blind, randomized, parallel-group

Multicenter, randomized, double-blind

Multicenter, randomized, double-blind

Multicenter, randomized, double-blind, parallel-group

Open-label, uncontrolled

Observational, open-label, uncontrolled, longitudinal, prospective

Multicenter, randomized, double-blind, parallel-group

Longitudinal, nonrandomized, prospective

Placebo

Enalapril

Atenolol

Enalapril

Enalapril

Enalapril

(ACEI)
Patients aged $\geq 18$ years with mild-to-moderate hypertension

$(n=215)$

Patients with severe hypertension

$(\mathrm{n}=182)$

Placebo, losartan

Patients with mild-to-moderate hypertension $(\mathrm{n}=567)$

Patients with mild-to-moderate hypertension $(\mathrm{n}=319)$

Patients with mild-to-moderate hypertension $(n=432)$

Olmesartan, losartan, valsartan

Patients aged $\geq 18$ years with essential hypertension $(\mathrm{n}=588)$

Patients with mild-to-moderate hypertension $(\mathrm{n}=238)$

Patients aged $\geq 18-75$ years, with mild-to-moderate hypertension

$(n=426)$

Patients with mild-to-moderate hypertension $(\mathrm{n}=25)$

Patients aged $\geq 18$ years, with mild-to-moderate hypertension

$(n=4,612)$

Patients with mild-to-moderate hypertension $(n=|8|)$

Enalapril, captopril, perindopril
Patients with hypertension (nondiabetic advanced chronic kidney disease)

$(n=43)$ 


\begin{tabular}{llll}
\hline Duration of therapy and & Baseline mean & Mean reduction & Conclusion \\
treatment dose $(\mathrm{mg})$ & SBP/DBP & in SBP/DBP & \\
& $(\mathrm{mmHg})$ & $(\mathrm{mmHg})$ & \\
&
\end{tabular}

8-week;

Irbesartan 75

Irbesartan 75 twice daily

Irbesartan 150

Placebo

I2-week;

Irbesartan 150-300

Enalapril 20-40

8-week;

Irbesartan 150

Irbesartan 300

Losartan 100

Placebo

8-week;

Irbesartan 100-300

Placebo

12-week:

Irbesartan 150-300

Losartan 50

12-week;

Irbesartan 75-150

Atenolol 50-100

12-week;

Irbesartan 75-300

Enalapril 10-40

8-week;

Irbesartan 150-300

Enalapril 10-20

8-week;

Irbesartan 150-300

Enalapril 10-20

8-week;

Irbesartan 150

Losartan 50

Valsartan 80

Olmesartan 20

I2-week;

Irbesartan 150-300

Enalapril 10-20

8-week;

Irbesartan 150

Valsartan 80

8-week;

Irbesartan 150-300

6-month;

Irbesartan 150-300

4-week;

Irbesartan 150

Amlodipine 5

I2-months;

Irbesartan 150-300

ACEI

\begin{tabular}{|c|c|}
\hline$|43.8 / 9| .6$ & $5.2 / 2.8$ \\
\hline$|44.4 / 9| .0$ & $10.9 / 9.2$ \\
\hline$|43.0 / 9| .0$ & $7.3 / 5.7$ \\
\hline$|45.2 / 9| .3$ & $0.1 / 1.2$ \\
\hline $119.2 / 176.7$ & $40.1 / 29.6$ \\
\hline $119.0 / 175.4$ & $39.3 / 30.5$ \\
\hline I55.3/I0I.| & $12.1 / 9.7$ \\
\hline I55.4/I00.4 & $16.4 / 11.7$ \\
\hline $153.3 / 100.6$ & | I.3/8.7 \\
\hline I52.4/I00.3 & $3.7 / 4.9$ \\
\hline \multirow[t]{2}{*}{$159.8 / 100.7$} & $13.0 / 11.6$ \\
\hline & $5.0 / 5.5$ \\
\hline $155.3 / 100.9$ & $18.0 / 13.8$ \\
\hline $154.2 / 100.7$ & $10.8 / 13.9$ \\
\hline $158.0 / 101.9$ & $15.0 / 12.3$ \\
\hline$|58.4 / 10| .3$ & $13.2 / 11.6$ \\
\hline $164 / 101$ & $19 / 13$ \\
\hline $165 / 102$ & $18 / 14$ \\
\hline 164.4/99.7 & $10.1 / 9.6$ \\
\hline $161.5 / 98.3$ & II.6/9.8 \\
\hline $155 / 102$ & $16.5 / 7.2$ \\
\hline$|55 / 10|$ & $10.6 / 5.0$ \\
\hline $156 / 104$ & $11.0 / 9.9$ \\
\hline $157 / 104$ & $9.5 / 8.2$ \\
\hline $155 / 104$ & $8.4 / 7.9$ \\
\hline $157 / 104$ & $11.3 / 11.5$ \\
\hline $160.3 / 101.6$ & $19.0 / 12.7$ \\
\hline $158.2 / 102.0$ & 17.512 .4 \\
\hline $159.3 / 100.7$ & $19.0 / 12.7$ \\
\hline $158 / 100.8$ & $17.5 / 12.4$ \\
\hline
\end{tabular}

After treatment: 128/82

After treatment: 140.0/82.5

12.2/9.4

12.0/9.6

After treatment:

138/77

$133 / 77$
All irbesartan regimens significantly reduced mean 24-hour ambulatory DBP and SBP and were well tolerated

Irbesartan effectively and safely reduced SBP and DBP in patients with severe hypertension in a manner comparable to that of enalapril

Antihypertensive effect of $300 \mathrm{mg}$ irbesartan was significantly greater than that of $100 \mathrm{mg}$ losartan

Irbesartan reduced BP in a dose-related manner; significant reductions over placebo were observed

Reductions in trough seated DBP and seated SBP were greater with irbesartan than with losartan treatment

Both treatments significantly lowered BP from baseline; irbesartan demonstrated an excellent safety and tolerability profile

Irbesartan was as effective as the full dose range of enalapril and demonstrated an excellent tolerability profile

Irbesartan is an effective and well tolerated antihypertensive treatment for elderly patients with mild-to-moderate hypertension

Irbesartan was as effective in lowering BP as enalapril; both treatments were well tolerated, while there was a significantly lower incidence of cough with irbesartan compared with enalapril

Irbesartan compared with olmesartan showed similar reductions in ambulatory BP and seated SBP; however it was found to be less effective at reducing diastolic $\mathrm{BP}$

Irbesartan was as effective as enalapril up to $20 \mathrm{mg} /$ day; irbesartan though, was better tolerated than enalapril

Irbesartan was more effective than valsartan in reducing DBP and SBP at trough and in providing greater overall 24-hour BPlowering efficacy

Irbesartan monotherapy once daily provided effective BP control

Irbesartan produced significant reductions in BP and was well tolerated

Irbesartan $150 \mathrm{mg}$ demonstrated comparable efficacy to amlodipine $5 \mathrm{mg}$, thereby confirming its value as an antihypertensive treatment option

Irbesartan compared with ACEl showed similar blood pressure control 
Table I (Continued)

\begin{tabular}{|c|c|c|c|}
\hline References & Study design & Comparator & Population \\
\hline Kawano et $\mathrm{a}^{61}$ & $\begin{array}{l}\text { Randomized, double-blind, } \\
\text { placebo-controlled }\end{array}$ & Placebo & $\begin{array}{l}\text { Patients with essential hypertension } \\
(n=76)\end{array}$ \\
\hline \multicolumn{4}{|c|}{ Combination therapy } \\
\hline Rosenstock et $\mathrm{al}^{53}$ & $\begin{array}{l}\text { Multicenter, randomized, } \\
\text { double-blind, placebo-controlled }\end{array}$ & Placebo/HCTZ & $\begin{array}{l}\text { Patients aged } \geq 28 \text { years to } 76 \text { years, with } \\
\text { mild-to-moderate essential hypertension } \\
(n=238)\end{array}$ \\
\hline Kochar et al71 & Matrix & Placebo & Patients with mild-to-moderate hypertension \\
\hline
\end{tabular}

\begin{tabular}{|c|c|c|c|}
\hline Raskin et $\mathrm{al}^{55}$ & $\begin{array}{l}\text { Randomized, double-blind, } \\
\text { placebo-controlled }\end{array}$ & $\begin{array}{l}\text { Irbesartan } \\
\text { HCTZ }\end{array}$ & $\begin{array}{l}\text { Patients aged } \geq 18 \text { years with mild-to-moderate } \\
\text { essential hypertension } \\
(n=1098)\end{array}$ \\
\hline Howe et $\mathrm{al}^{54}$ & $\begin{array}{l}\text { Randomized, double-blind, } \\
\text { placebo-controlled }\end{array}$ & Placebo & $\begin{array}{l}\text { Patients aged } \geq 21 \text { years with mild-to-moderate } \\
\text { essential hypertension } \\
(n=178)\end{array}$ \\
\hline Bobrie et $\mathrm{al}^{58}$ & $\begin{array}{l}\text { Randomized, prospective, open-label, } \\
\text { blinded endpoint }\end{array}$ & Valsartan/HCTZ & $\begin{array}{l}\text { Patients }>18 \text { years and }<80 \text { years with untreated or } \\
\text { uncontrolled hypertension } \\
(n=4 \mid 4)\end{array}$ \\
\hline Neutel et $\mathrm{al}^{59}$ & $\begin{array}{l}\text { Randomized, parallel-group, } \\
\text { open-label }\end{array}$ & Losartan/HCTZ & $\begin{array}{l}\text { Patients with mild-to-moderate hypertension } \\
(n=16)\end{array}$ \\
\hline Neutel et $\mathrm{al}^{75}$ & $\begin{array}{l}\text { Multicenter, prospective, open-label, } \\
\text { single-arm (INCLUSIVE) }\end{array}$ & $\begin{array}{l}\text { Placebo } \\
\text { HCTZ }\end{array}$ & $\begin{array}{l}\text { Patients aged } \geq 18 \text { years with hypertension } \\
\text { and uncontrolled systolic BP } \\
(n=736)\end{array}$ \\
\hline Neutel et $\mathrm{al}^{73}$ & $\begin{array}{l}\text { Multicenter, randomized, double-blind, } \\
\text { active-controlled }\end{array}$ & Irbesartan & $\begin{array}{l}\text { Patients with uncontrolled hypertension } \\
(n=697)\end{array}$ \\
\hline Franklin et $\mathrm{al}^{68}$ & $\begin{array}{l}\text { Multicenter, randomized, double-blind, } \\
\text { active-controlled, forced-titration }\end{array}$ & $\begin{array}{l}\text { Irbesartan } \\
\text { HCTZ }\end{array}$ & $\begin{array}{l}\text { Patients with moderate and severe hypertension } \\
(\mathrm{n}=1235)\end{array}$ \\
\hline Cushman et $\mathrm{al}^{64}$ & Prospective, open-label, single-arm & $\begin{array}{l}\text { Placebo } \\
\text { HCTZ }\end{array}$ & $\begin{array}{l}\text { Patients aged } \geq 18 \text { years with hypertension } \\
(n=844)\end{array}$ \\
\hline Neutel et $\mathrm{al}^{76}$ & $\begin{array}{l}\text { Randomized, double-blind, } \\
\text { active-controlled, parallel-group }\end{array}$ & $\begin{array}{l}\text { Irbesartan } \\
\text { HCTZ }\end{array}$ & $\begin{array}{l}\text { Patients with moderate hypertension } \\
(n=538)\end{array}$ \\
\hline Ofili et $\mathrm{al}^{74}$ & $\begin{array}{l}\text { Multicenter, prospective, open-label, } \\
\text { single-arm (INCLUSIVE I) }\end{array}$ & & $\begin{array}{l}\text { Patients (women) aged } \geq 18 \text { years with hypertension } \\
(n=436)\end{array}$ \\
\hline Fogari et $\mathrm{al}^{67}$ & $\begin{array}{l}\text { Prospective, randomized, open-label, } \\
\text { blinded, end-point (PROBE) }\end{array}$ & Valsartan/amlodipine & $\begin{array}{l}\text { Very elderly patients with hypertension } \\
(\mathrm{n}=94)\end{array}$ \\
\hline
\end{tabular}




\begin{tabular}{|c|c|c|c|}
\hline $\begin{array}{l}\text { Duration of therapy and } \\
\text { treatment dose }(\mathrm{mg})\end{array}$ & $\begin{array}{l}\text { Baseline mean } \\
\text { SBP/DBP } \\
(\mathrm{mmHg})\end{array}$ & $\begin{array}{l}\text { Mean reduction } \\
\text { in } \mathrm{SBP} / \mathrm{DBP} \\
(\mathrm{mmHg})\end{array}$ & Conclusion \\
\hline 6-week; & & & Irbesartan significantly reduced 24-hour daytime and night-time \\
\hline Irbesartan 100 & $145.0 / 95.0$ & $5.8 / 3.4$ & BPs compared with placebo; overall safety was even greater for \\
\hline Placebo & $142.9 / 92.0$ & $1.7 / 0.5$ & irbesartan than placebo \\
\hline I2-week; & & & Irbesartan/HCTZ produced clinically and statistically significant \\
\hline Irbesartan/HCTZ 75-150/25 & 145.8/98.6 & $20.2 / 18.4$ & mean reductions over placebo in both trough seated SBP and \\
\hline Placebo/HCTZ 25 & 147.8/99.0 & $6.0 / 7.4$ & DBP and a significant antihypertensive response \\
\hline 8-week; & & Range & The combination of HCTZ in doses up to $25 \mathrm{mg}$ with irbesartan \\
\hline Irbesartan 37.5, 100 , and 300 & $151 / 100$ & $7.5-14.9 / 7.1-10.2$ & in doses up to $300 \mathrm{mg}$ is safe and produces dose-dependent \\
\hline HCTZ 6.25, 12.5 , and 25 & & $4.6-\mid 1.5 / 5.1-15.0$ & reductions in $\mathrm{BP}$ \\
\hline irbesartan/HCTZ 37.5-300/ & & $10.2-23.1 / 8.1-15.0$ & \\
\hline $6.25-25$ & & $2.3 / 3.5$ & \\
\hline \multicolumn{4}{|l|}{ Placebo } \\
\hline I2-month; & & & Long-term therapy with irbesartan/HCTZ is safe, well tolerated, \\
\hline Irbesartan/HCTZ 75-300/I2.5-25 & $151.6 / 100.4$ & $20.6 / 15.6$ & and maintains normalized BP in $>80 \%$ of patients \\
\hline 8-week; & & & Irbesartan/HCTZ produced clinically and statistically significant \\
\hline Irbesartan/HCTZ 75// 2.5 & $150.2 / 93.4$ & $21.6 / 12.0$ & mean reductions in 24-hour ABP compared with placebo \\
\hline Irbesartan/HCTZ I50//2.5 & $152.6 / 93.5$ & $22.1 / 13.5$ & \\
\hline Placebo & 148.3/93.2 & $6.4 / 3.5$ & \\
\hline 24-week; & & & Irbesartan alone or combined with HCTZ showed excellent \\
\hline $\begin{array}{l}\text { Irbesartan/HCTZ I50-300/ } \\
\text { I2.5-25 }\end{array}$ & $136.5 / 84.8$ & $28.1 / 20.0$ & antihypertensive efficacy with a low incidence of adverse events \\
\hline 8-week; & $|53 / 9|$ & 14.8/8.2 & Irbesartan/HCTZ is more effective than valsartan/HCTZ in \\
\hline Irbesartan/HCTZ I50/I 2.5 & $153 / 90$ & $11.6 / 6.8$ & hypertensive patients \\
\hline \multicolumn{4}{|l|}{ Valsartan/HCTZ 80/I 2.5} \\
\hline 4-week; & & & Irbesartan $50 \mathrm{mg} / \mathrm{HCTZ} 12.5 \mathrm{mg}$ resulted in greater reductions \\
\hline Irbesartan/HCTZ I50//2.5 & $149.2 / 92.6$ & $16.0 / 10.5$ & in ambulatory BP than losartan $50 \mathrm{mg} / \mathrm{HCTZ} 12.5 \mathrm{mg}$ \\
\hline Losartan/HCTZ 50/I2.5 & $142.7 / 89.0$ & $\mid 1.1 / 6.1$ & \\
\hline I8-week; & & & Irbesartan/HCTZ treatment achieved SBP goals in more than \\
\hline $\begin{array}{l}\text { Irbesartan/HCTZ I50-300/ } \\
\text { |2.5-25 }\end{array}$ & $|54.0 / 9| .3$ & $21.5 / 10.4$ & $75 \%$ of patients uncontrolled on monotherapy \\
\hline 7-week; & & & In patients with severe hypertension, irbesartan/HCTZ \\
\hline Irbesartan I50-300 & $171.6 / 113.3$ & $31.7 / 24.5$ & combination therapy lowered BP more rapidly and to a greater \\
\hline Irbesartan/HCTZ I50-300/ & $171.5 / 113.4$ & & extent than maximum-dose irbesartan monotherapy \\
\hline \multicolumn{4}{|r|}{ 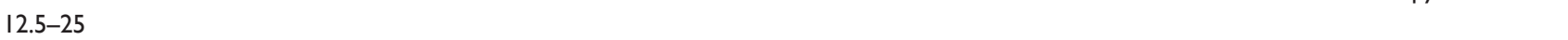 } \\
\hline I2-week; & & & Irbesartan/HCTZ combination therapy was well tolerated \\
\hline Irbesartan 300 & $168.4 / 108.4$ & $21.7 / 17.3$ & and more effective than irbesartan or HCTZ monotherapy in \\
\hline HCTZ 25 & $162.0 / 97.6$ & $15.7 / 7.2$ & lowering BP in patients with moderate-to-severe hypertension \\
\hline Irbesartan/HCTZ 300/25 & $167.5 / 106.8$ & $29.9 / 20.4$ & \\
\hline 8-week; & & & Irbesartan/HCTZ combination therapy allowed SBP goal \\
\hline HCTZ 12.5 & $156.5 / 85.6$ & $31.7 / 24.5$ & attainment in $73 \%$ of patients aged $>65$ years whose \\
\hline Irbesartan/HCTZ I50-300//2.5-25 & & & hypertension was previously uncontrolled with monotherapy \\
\hline I2-week; & & & Irbesartan/HCTZ is well tolerated and achieves rapid and \\
\hline Irbesartan/HCTZ I50-300//2.5-25 & $161.7 / 97.5$ & $28.3 / 15.2$ & sustained reductions in SBP/DBP in patients with moderate \\
\hline Irbesartan 150-300 & $161.4 / 97.9$ & $19.5 / 11.1$ & hypertension \\
\hline НСTZ I2.5-25 & $162 / 97.6$ & $16.5 / 7.8$ & \\
\hline 8-week; & & & Irbesartan/HCTZ treatment was effective and well tolerated \\
\hline Irbesartan/HCTZ 300/25 & $153.9 / 90.3$ & $22.9 / 10.3$ & $\begin{array}{l}\text { in a diverse population of women whose BP was previously } \\
\text { uncontrolled on monotherapy }\end{array}$ \\
\hline 4-week; & & & In very elderly hypertensive patients, treatment with both \\
\hline Valsartan/amlodipine $160 / 5$ & $163.2 / 89.8$ & $22.9 / 15.6$ & valsartan/amlodipine combination and irbesartan/HCTZ \\
\hline Irbesartan/HCTZ 300/I 2.5 & 162.7/90.1 & $29.6 / 15.4$ & $\begin{array}{l}\text { combination was similarly effective in reducing clinical as well as } \\
\text { ambulatory BP levels }\end{array}$ \\
\hline
\end{tabular}


Table I (Continued)

\begin{tabular}{|c|c|c|c|}
\hline References & Study design & Comparator & Population \\
\hline Chrysant et $a^{66}$ & $\begin{array}{l}\text { Multicenter, prospective, open-label, } \\
\text { single-arm (INCLUSIVE trial) }\end{array}$ & $\begin{array}{l}\text { Placebo } \\
\text { HCTZ }\end{array}$ & $\begin{array}{l}\text { Patients aged } \geq 18 \text { years with isolated systolic } \\
\text { hypertension } \\
(n=443)\end{array}$ \\
\hline Franklin and Neutel ${ }^{69}$ & Randomized double-blind trial & No comparator & $\begin{array}{l}\text { Patients with severe uncontrolled hypertension } \\
(n=468)\end{array}$ \\
\hline Bobrie et $\mathrm{al}^{57}$ & $\begin{array}{l}\text { Multicenter, parallel-group, } \\
\text { prospective, randomized, open-label, } \\
\text { blinded endpoint (I-COMBINE) }\end{array}$ & Amlodipine & $\begin{array}{l}\text { Patients with essential, uncontrolled hypertension } \\
(n=287)\end{array}$ \\
\hline Bobrie et $\mathrm{al}^{56}$ & $\begin{array}{l}\text { Multicenter, parallel-group, prospective, } \\
\text { randomized, parallel-group, open-label, } \\
\text { blinded-end point (I-AAD) }\end{array}$ & Irbesartan & $\begin{array}{l}\text { Patients with essential, uncontrolled hypertension } \\
(n=320)\end{array}$ \\
\hline Al Balushi et al ${ }^{65}$ & Retrospective, observational & Valsartan/HCTZ & $\begin{array}{l}\text { Patients with mild-to-moderate hypertension } \\
(\mathrm{n}=232)\end{array}$ \\
\hline Huang et $\mathrm{al}^{70}$ & Multicenter, single-arm, prospective & No comparator & $\begin{array}{l}\text { Patients with moderate-to-severe hypertension } \\
(\mathrm{n}=50 \mathrm{I})\end{array}$ \\
\hline
\end{tabular}

Abbreviations: HCTZ, hydrochlorothiazide; ACEl, angiotensin-converting enzyme inhibitor; BP, blood pressure; DBP, diastolic blood pressure; SBP, systolic blood pressure; T2DM, type 2 diabetes mellitus.

both microalbuminuric normotensive and hypertensive patients as well as 24-hour mean systolic and diastolic BP. ${ }^{81}$

\section{Effects of irbesartan on left ventricular hypertrophy}

Left ventricular hypertrophy increases the risk of cardiovascular disease in patients with hypertension, and there are several studies investigating the potential effects of irbesartan in patients with left ventricular hypertrophy. ${ }^{82-85}$ In the SILVHIA (Swedish Irbesartan Left Ventricular Hypertrophy Investigation versus Atenolol) trial, patients treated with irbesartan showed a greater reduction in left ventricular mass and BP than those treated with atenolol. Irbesartan decreased QT dispersion from $56 \pm 24 \mathrm{msec}$ to $45 \pm 20 \mathrm{msec}$ at 48 weeks and QTc dispersion from $57 \pm 24 \mathrm{msec}$ to $44 \pm 19 \mathrm{msec}^{83}$ Similarly, the effect of irbesartan $150 \mathrm{mg}$ once daily in patients with essential arterial hypertension and echocardiographically determined left ventricular hypertrophy showed a decrease by $23.2 \%$ and $24.7 \%$ in left ventricular mass index compared with a decrease of $11.4 \%$ and $11.6 \%$ with amlodipine (after 3 months and 6 months, respectively). ${ }^{82}$

\section{Cost-effectiveness}

The literature review identified 15 papers eligible for inclusion in the review concerning the cost-effectiveness of irbesartan. More specifically, 13 studies compared the cost-effectiveness of irbesartan with standard antihypertensive medications (amlodipine, valsartan, losartan), while the other two assessed the cost-effectiveness of irbesartan in combination with HCTZ. The studies are presented in Table 2 and the results are summarized under the following headings: study reference, analysis perspective, methods, population, time horizon, discounting rate, costs, outcomes, and study conclusions. The majority of the studies based their efficacy data on two clinical trials, ie, IDNT and IRMA-2. All studies were modeling ones, using a Markov model, with the majority being cost-effectiveness analy$\operatorname{ses}^{86-94}$ or cost-consequence analyses, ${ }^{95-99}$ while one was a cost utility analysis. ${ }^{100}$ Studies were done either from a third party payer perspective or from a health care payer perspective. The population under consideration included patients with hypertension, type 2 diabetes, microalbuminuria, and nephropathy. The majority of the studies were conducted in a European setting (France, Belgium, the UK, Spain, Hungary, Italy, Greece, Switzerland, and Sweden), while two were conducted in the US, two in Canada, and another one in Asia.

In many of the studies, there are extrapolations on the long-term life years gained and quality-adjusted years with irbesartan. In four studies comparing irbesartan with 


\begin{tabular}{|c|c|c|c|}
\hline $\begin{array}{l}\text { Duration of therapy and } \\
\text { treatment dose }(\mathrm{mg})\end{array}$ & $\begin{array}{l}\text { Baseline mean } \\
\text { SBP/DBP } \\
(\mathrm{mmHg})\end{array}$ & $\begin{array}{l}\text { Mean reduction } \\
\text { in SBP/DBP } \\
(\mathrm{mmHg})\end{array}$ & Conclusion \\
\hline $\begin{array}{l}\text { I6-week; } \\
\text { HCTZ I } 2.5 \\
\text { Irbesartan/HCTZ I50-300//2.5-25 }\end{array}$ & 156.2/88.7 & $21.4 / 10.1$ & $\begin{array}{l}\text { Once-daily fixed-dose irbesartan/HCTZ combination treatment } \\
\text { provided effective and well tolerated BP-lowering }\end{array}$ \\
\hline $\begin{array}{l}\text { 7-week; } \\
\text { Irbesartan/HCTZ 300/25 }\end{array}$ & $191.2 /|15|$. & $\begin{array}{l}\text { Range } \\
28.0-42.9 / \\
22.9-27.2\end{array}$ & $\begin{array}{l}\text { Irbesartan/HCTZ was rapidly effective regardless of age, obesity, } \\
\text { T2DM, and baseline SBP; treatment was well tolerated }\end{array}$ \\
\hline $\begin{array}{l}\text { 10-week; } \\
\text { Irbesartan/amlodipine 150/5 } \\
\text { Amlodipine } 5\end{array}$ & $\begin{array}{l}148.5 / 84.8 \\
|49.2 / 85 .|\end{array}$ & $\begin{array}{l}12.4 / 5.6 \\
6.3 / 3.0\end{array}$ & $\begin{array}{l}\text { Fixed-dose combination irbesartan/amlodipine suggests greater } \\
\text { efficacy over monotherapy in lowering SBP }\end{array}$ \\
\hline $\begin{array}{l}\text { I0-week; } \\
\text { Irbesartan/amlodipine 300/5 }\end{array}$ & I52.7/86.6 & $18.7 / 8.6$ & $\begin{array}{l}\text { There was a greater antihypertensive efficacy of the fixed-dose } \\
\text { combination of irbesartan 300/amlodipine } 5 \mathrm{mg} \text { over irbesartan }\end{array}$ \\
\hline Irbesartan 300 & $150.4 / 86.0$ & $9.9 / 3.9$ & $\begin{array}{l}300 \text { alone in lowering systolic BP; both treatments were } \\
\text { well tolerated }\end{array}$ \\
\hline $\begin{array}{l}\text { 3-month; } \\
\text { Irbesartan/HCTZ I50/I2.5 }\end{array}$ & $|53 / 8|$ & $9.0 / 5.0$ & $\begin{array}{l}\text { The irbesartan/HCTZ combination was associated with } \\
\text { significant reductions in both SBP and DBP when compared with }\end{array}$ \\
\hline Valsartan/HCTZ 80-160//2.5 & $144 / 77$ & $2.0 / 0.0$ & $\begin{array}{l}\text { valsartan/HCTZ combinations; reductions were noted more in } \\
\text { diabetics than nondiabetics }\end{array}$ \\
\hline $\begin{array}{l}\text { I2-week; } \\
\text { Irbesartan/HCTZ I 50-300//2.5-25 }\end{array}$ & $161.5 / 99.5$ & $27.8 / 13.5$ & $\begin{array}{l}\text { The fixed irbesartan/HCTZ combination may control BP to the } \\
\text { target level in about } 60 \% \text { of Chinese patients with moderate-to- } \\
\text { severe hypertension, with an acceptable safety profile }\end{array}$ \\
\hline
\end{tabular}

amlodipine treatment, results concerning effectiveness showed that life expectancy improved with irbesartan compared with amlodipine. Life expectancy for irbesartan was 8.58 life years in a 25-year time horizon versus 8.13 life years with amlodipine. ${ }^{88,91,94-96}$ Five studies comparing early versus late irbesartan treatment showed that early irbesartan is more effective than late irbesartan. ${ }^{86,87,92,98,100}$ Life years gained with irbesartan were 12.17 versus 11.27 with late irbesartan treatment. The quality-adjusted life years gained were 10.55 and 9.58 , respectively. ${ }^{100}$ Further, several studies indicated an association between irbesartan treatment and delayed onset of end-stage renal disease (ESRD). Results showed that use of irbesartan delayed the onset of ESRD and reduced the cumulative incidence of ESRD apart from increasing life expectancy. The cumulative incidence of ESRD after 25 years for irbesartan compared with control therapy was $10.7 \%-26.6 \%$, respectively. Irbesartan was estimated to delay the onset of ESRD by 2.14 years. ${ }^{97}$

Results concerning the cost-effectiveness of irbesartan monotherapy compared with conventional antihypertensive therapy reveal that treatment of hypertensive patients with type 2 diabetes, microalbuminuria, and nephropathy with irbesartan lead to significant cost savings. More specifically, total per patient costs with irbesartan ranged from approximately $€ 14,000$ to $€ 93,000$. Corresponding costs per patient with the comparison treatment ranged from approximately $€ 20,000$ to $€ 120,000$, resulting to substantial cost savings of up to about $€ 20,000$ with irbesartan treatment.

Four studies evaluated the cost-effectiveness of three alternative strategies for the management of hypertensive patients with type 2 diabetes and microalbuminuria; these alternative strategies were early irbesartan treatment, late irbesartan treatment, and conventional antihypertensive treatment. ${ }^{86,87,92,98}$ Results from these studies showed that early irbesartan treatment is cost-effective compared with late irbesartan treatment and conventional antihypertensive therapy, resulting to cost savings per patient of up to approximately $€ 40,000$ versus late irbesartan treatment and up to approximately $€ 50,000$ versus standard treatment. ${ }^{86,87,92,98}$

Two studies evaluating irbesartan in combination with HCTZ for the treatment of patients with hypertension showed that irbesartan is a cost-effective antihypertensive treatment strategy compared with alternative hypertension therapies, losartan and valsartan. ${ }^{89,90}$ More specifically, the combination of irbesartan $150 \mathrm{mg} / \mathrm{HCTZ} 12.5 \mathrm{mg}$ was a dominant strategy (ie, better health effects at lower costs) compared with losartan $50 \mathrm{mg} / \mathrm{HCTZ} 12.5 \mathrm{mg}$ and valsartan $80 \mathrm{mg} / \mathrm{HCTZ}$ $12.5 \mathrm{mg}^{89}$ 
Table 2 Methodologic characteristics of economic evaluation studies

\begin{tabular}{lllll}
\hline Reference & $\begin{array}{l}\text { Analysis } \\
\text { perspective }\end{array}$ & Methods & Population & $\begin{array}{l}\text { Time horizon } \\
\text { discount rate }\end{array}$ \\
\hline Rodby et al ${ }^{94}$ & $\begin{array}{l}\text { Third party payer } \\
\text { (Medicare) }\end{array}$ & CEA based on a Markov model & $\begin{array}{l}\text { Patients with type 2 diabetes, } \\
\text { hypertension, and nephropathy }\end{array}$ & 25 years, 5\% \\
& & & M
\end{tabular}

Palmer et a ${ }^{96} \quad$ Third party payer $\quad$ CCA based on a Markov model (Medicare)

Palmer et al ${ }^{92}$

Third party payer

CEA based on a Markov mode

Palmer et a $9^{95}$

NHS payer

CCA based on a Markov model

Palmer et $\mathrm{al}^{93}$

Third party payer

CEA based on a Markov model

Palmer et al ${ }^{91}$

Health care payer

CEA based on a Markov model

Palmer et al ${ }^{97}$

Third party payer

CCA based on a Markov model

Palmer et al ${ }^{100}$

Third party payer
Patients with type 2 diabetes, hypertension, and nephropathy
10 years, $3 \%$

25 years, $3 \%$

Patients with type 2 diabetes, hypertension, and microalbuminuria

Patients with type 2 diabetes, hypertension, and nephropathy

10 years, $6 \%$

Patients with type 2 diabetes, hypertension, and microalbuminuria

25 years, $3 \%$

Patients with type 2 diabetes, hypertension, and nephropathy

25 years, $5 \%$

Patients with type 2 diabetes,

25 years, $5 \%$ hypertension, and microalbuminuria

Patients with type 2 diabetes, and hypertension
25 years, $3 \%$ 


\begin{tabular}{|c|c|}
\hline Costs & Outcomes \\
\hline TC/patient (25 years): & LE (25 years): \\
\hline Irbesartan $\$ 1$ I I,647 versus amlodipine $\$ 137,937$ & Irbesartan 8.225 versus amlodipine \\
\hline versus control $\$ 127,254$ & 7.601 versus placebo 7.484 \\
\hline \multicolumn{2}{|l|}{ Cost savings ( 25 years): } \\
\hline \multirow{2}{*}{\multicolumn{2}{|c|}{$\begin{array}{l}\text { Irbesartan versus amlodipine } \$ 26,290 \text { versus } \\
\text { control } \$ 15,607\end{array}$}} \\
\hline & \\
\hline Lifetime TC/patient: & Mean time to ESRD (years): \\
\hline Belgium: Irbesartan $€ 76,777$ versus amlodipine & Irbesartan 8.23 versus amlodipine \\
\hline$€ 97,940$ versus control $€ 88,662$ & 6.82 versus control 7.88 \\
\hline France: Irbesartan $€ 93,204$ versus amlodipine & LE (years): \\
\hline$€ \mid 20,284$ versus control & Belgium: Irbesartan 8.57 versus \\
\hline$€ 109,585$ & amlodipine 8.11 versus control 7.95 \\
\hline Cost savings/patient: & France: Irbesartan 8.58 versus \\
\hline Belgium: Irbesartan versus amlodipine: $€ \mid 4,949$ & amlodipine 8.13 versus control 7.97 \\
\hline
\end{tabular}

versus control: $€ 9,205$

France: Irbesartan versus amlodipine: $€ 20,128$ versus control: $€ \mid 3,337$

TC/patient ( 25 years):

Early irbesartan: $\$ 16,859$

Late irbesartan: $\$ 25,529$

Control: $\$ 28,782$

Cost savings/patient:

Early irbesartan versus control: $\$ 11,922$

Late irbesartan versus control: $\$ 3,252$

Early versus late irbesartan: $\$ 8,670$

Mean TC/patient ( 10 years):

Irbesartan $£ 20,884$ versus amlodipine $£ 27,417$

versus control $£ 24,642$

Cost savings/patient (ESRD delay):

Irbesartan versus amlodipine $£ 5,125$ versus

control $£ 2,919$

TC/patient ( 25 years):

Irbesartan: $€ \mid 4,038$

Control: $€ 25,119$

Cost savings/patient (25 years):

Irbesartan versus control $€ \mid I, 082$

TC/patient ( 10 years):

Irbesartan $€ 41,692$ versus amlodipine $€ 55,222$

versus placebo $€ 49,825$

Cost saving/patient ( 10 years):

Irbesartan versus amlodipine $€ \mid 3,530$;

versus placebo $€ 8,133$

TC/patient (25 years):

Irbesartan CHF 25,469 versus control CHF 46,956

Cost savings/patient (25 years):

Irbesartan versus control CHF 2I,487

TC/patient ( 25 years):

Early irbesartan $€ 17,689$ versus late irbesartan

$€ 33,383$ versus control $€ 40,003$
Years free of ESRD:

Early irbesartan: 14.4

Late irbesartan: 12.7

Control: 12.4

LYG/patient:

Early versus control 0.96 ;

late versus control 0.05 ;

early versus late 0.92

LE (years):

Irbesartan versus amlodipine 0.07

versus control 0.21

Years free of ESRD:

Irbesartan I 5.66 versus control I 3.44 LE (years):

Irbesartan I2.37 versus control II.53

Mean time to ESRD (years):

Irbesartan 8.23 versus amlodipine

6.82 versus placebo 6.88

Increase in LE ( 10 years):

Irbesartan 0.15 versus amlodipine

0.31 versus placebo 0.31

Mean LE (years):

Irbesartan 10.37 versus control 9.80

Years free of ESRD:

Irbesartan I5.04 versus control 12.90

LYG:

Early irbesartan 12.17 versus late

irbesartan II.27 versus control II.23

QALY:

Early irbesartan 10.55 versus late

irbesartan 9.58 versus control 9.52

Study conclusion

Irbesartan was both the least costly and most effective strategy

Irbesartan was both cost-saving and life-saving compared with amlodipine and control therapy

Early irbesartan treatment reduces costs in hypertensive patients with type 2 diabetes and microalbuminuria; late irbesartan is also superior in overt nephropathy but should start earlier and continued long term

Treating patients with hypertension, type 2 diabetes, and overt nephropathy with irbesartan was cost-saving over a 10-year period compared with amlodipine and control

Treating patients with hypertension, microalbuminuria and type 2 diabetes with irbesartan was projected to reduce the incidence of ESRD, extend life, and reduce costs

Irbesartan is a life-saving and cost-saving drug in patient with type 2 diabetes compared with amlodipine and standard blood pressure treatment

Irbesartan treatment of type 2 diabetes patients with hypertension and microalbuminuria is both cost and life-saving

Early irbesartan treatment improved quality of life and reduced costs compared with late irbesartan treatment 
Table 2 (Continued)

\begin{tabular}{llll}
\hline Reference & $\begin{array}{l}\text { Analysis } \\
\text { perspective }\end{array}$ & Methods & Population \\
\hline Palmer et al $^{98}$ & NHS payer & CCA based on a Markov model & $\begin{array}{l}\text { Patients with type 2 diabetes, } \\
\text { hypertension, and nephropathy }\end{array}$
\end{tabular}

Palmer et al ${ }^{99} \quad$ Third party payer (health insurance)

Coyle and Rodby ${ }^{88}$

Third party payer

CEA based on a Markov model

Coyle et $\mathrm{al}^{87}$

NHS payer

Annemans et $\mathrm{al}^{86}$

Third party payer

CEA based on a Markov model

Health care payer

CEA based on a Markov model hypertension, and nephropathy
25 years, $5 \%$

25 years, $5 \%$

25 years,

Not stated
Ekman et $a^{89}$

Maniadakis et $\mathrm{al}^{90}$
Third party payer
Patients with hypertension

Not stated

Patients with type 2 diabetes, hypertension, and proteinuria

Patients with type 2 diabetes, hypertension, and microalbuminuria

Patients with type 2 diabetes,

25 years, $3 \%$

Patients with hypertension

Not stated 


\begin{tabular}{l} 
Costs \\
\hline TC/patient ( 25 years): \\
Early irbesartan $€ 6,735$ versus late irbesartan $£ 9,045$ \\
versus control $€ 10,536$ \\
Cost savings/patient ( 25 years): \\
Early irbesartan versus control $€ 3,80 \mathrm{I}$ \\
Late irbesartan versus control $£|, 49|$
\end{tabular}

TC/patient ( 25 years): Irbesartan HUF I,250,204 versus placebo HUF I,770, 197

Cost saving/patient (25 years):

Irbesartan versus placebo HUF 519,993

\section{TC/patient (CAN\$):}

Irbesartan 89,304 versus amlodipine 109,280

versus control 101,688

\section{TC/patient (CAN\$):}

Early irbesartan $\$ 67,300$ versus late irbesartan

$\$ 121,400$ versus control $\$ 135,700$

Cost saving/patient (CAN\$):

Early irbesartan versus late irbesartan $\$ 54,100$

Early irbesartan versus control $\$ 68,400$

Late irbesartan versus control $\$ 14,300$

TC/patient (25 years):

Late irbesartan,

Early irbesartan

Malaysia $\$ 8,455$

South Korea $\$ 12,961$

Thailand $\$ 29,737$ standard treatment: $\$ 2,980$ to $\$ 13,484$, $\$ 6,189$ to $\$ 21,148$

Taiwan $\$ 25,790$ $\$ 8,200$ to $\$ 29,732$ People's Republic of China $\$ 42,990$ of early irbesartan Men:

Irbesartan/HCTZ (I50/I2.5 mg): €17,I07

Irbesartan/HCTZ (300/25 mg): €|7,37|

$\mathrm{C} / \mathrm{E}$ ratio: $€ 18,964$

Women:

Irbesartan/HCTZ (I50//2.5 mg): €|3,6। 0

Irbesartan/HCTZ (300/25 mg): €।3,9|2

C/E ratio: $€ 44,552$

\section{TC/patient:}

Mild-to-moderate hypertension

Men:

Irbesartan $€ \mid$ 5, I 46 versus losartan $€ \mid 5,696$

versus valsartan $€ I 5,6 \mid 3$

\section{Women:}

Irbesartan $€ \mid 2,945$ versus losartan $€ \mid 4,424$

versus valsartan €।3,397

Severe hypertension

Men:

Irbesartan $€ \mid 8,697$ versus losartan $€ 2 \mid, 488$

Women:

Irbesartan $€ \mid 6,202$ versus losartan $€ \mid 9,099$

\section{Outcomes}

\section{Years free of ESRD:}

Early irbesartan 14.29 versus late irbesartan 12.47 versus control 12.25 LE (years):

Early $\mathrm{I} I .00$ versus late 10.20 versus control 10.18

LYG:

Early versus control 0.83

Late versus control 0.02

LE (years):

Irbesartan 8.16 versus placebo 7.62

LYG:

Irbesartan versus placebo 0.54

LYG:

Irbesartan 6.82 versus Amlodipine

6.48 versus control 6.40

LYG:

Early versus late irbesartan 0.45

Early irbesartan versus control 0.62

Increase in LE (years):

Early versus late: 0.31 to 0.48

Men:

Irbesartan/HCTZ (150//2.5 mg):

13.067 QALY

Irbesartan/HCTZ (300/25 mg):

13.08। QALY

Women:

Irbesartan/HCTZ (I50//2.5 mg):

14. II 3 QALY

Irbesartan/HCTZ (300/25 mg):

14.120 QALY

\section{QALY}

Men:

Irbesartan 1.67 versus losartan 12.63

versus valsartan 12.64

\section{Women:}

Irbesartan 14.29 versus losartan

I 4.27 versus valsartan $\mid 4.27$

Men:

Irbesartan 12.47 versus losartan 12.37

Women:

Irbesartan 14.16 versus losartan 14.09
Study conclusion

Treatment with irbesartan was projected to improve life expectancy and reduce costs in patients with type 2 diabetes and hypertension at risk of developing ESRD

Irbesartan was projected to be a dominant treatment compared with placebo in the Hungarian setting when treating hypertensive patients with type 2 diabetes and microalbuminuria Irbesartan compared with amlodipine and standard care, led to reduction in medical costs and an increase in life expectancy Early use of irbesartan for patients with hypertension and type 2 diabetes is both more effective and less costly

Early irbesartan treatment was a cost-effective alternative in the Asian settings

Irbesartan/HCTZ is a cost-effective antihypertensive treatment strategy compared with placebo, valsartan, and losartan

Irbesartan combined with HCTZ compares favorably with losartan and valsartan in combination with HCTZ in Greece 


\section{Conclusion}

Evidence from this review suggests that irbesartan represents not only an effective and well tolerated treatment for patients with hypertension and those with type 2 diabetes and nephropathy, but also a cost-saving and cost-effective treatment compared with other conventional treatment options.

\section{Disclosure}

The authors report no conflicts of interest in this work.

\section{References}

1. World Health Organization. A global brief on hypertension. Silent killer, global public health crisis. Geneva, Switzerland: World Health Organization; 2013. Available from: http://www.who.int/cardiovascular_diseases/publications/global_brief_hypertension/en/. Accessed August 20, 2013.

2. Whitworth JA; World Health Organization, International Society of Hypertension Writing Group. 2003 World Health Organization (WHO)/ International Society of Hypertension (ISH) statement on management of hypertension. J Hypertens. 2003;21:1983-1992.

3. Wolf-Maier K, Cooper RS, Banegas JR, et al. Hypertension prevalence and blood pressure levels in 6 European countries, Canada, and the United States. JAMA. 2003;289:2363-2369.

4. Brunner HR. The new angiotensin II receptor antagonist, irbesartan: pharmacokinetic and pharmacodynamic considerations. Am J Hypertens. 1997;10(12 Pt 2):311S-317S.

5. Burnier M. Angiotensin II type 1 receptor blockers. Circ J. 2001;103: 904-912.

6. Waeber B. A review of the clinical experience with the angiotensin II Receptor antagonist irbesartan. Cardiovasc Drug Rev. 2000;18: $103-126$.

7. Tikkanen I, Jensen H. Comparison of the angiotensin II antagonist losartan with the angiotensin converting enzyme inhibitor enalapril in patients with essential hypertension. J Hypertens. 1995;13:1343-1351.

8. Ruff D, Gazdick LP, Berman R, Goldberg AI, Sweet CS. Comparative effects of combination drug therapy regimens commencing with either losartan potassium, an angiotensin II receptor antagonist, or enalapril maleate for the treatment of severe hypertension. J Hypertens. 1996;14:263-270.

9. Holwerda NJ, Fogari R, Angeli P, et al. Valsartan, a new angiotensin II antagonist for the treatment of essential hypertension: efficacy and safety compared with placebo and enalapril. J Hypertens. 1996;14: 1147-1151.

10. Gradman AH, Arcuri KE, Goldberg AI, et al. A randomized, placebocontrolled, double-blind, parallel study of various doses of losartan potassium compared with enalapril maleate in patients with essential hypertension. Hypertension. 1995;25:1345-1350.

11. Goldberg AI, Dunlay MC, Sweet CS. Safety and tolerability of losartan potassium, an angiotensin II receptor antagonist, compared with hydrochlorothiazide, atenolol, felodipine ER, and angiotensin-converting enzyme inhibitors for the treatment of systemic hypertension. Am J Cardiol. 1995;75:793-795.

12. Weber MA, Byyny RL, Pratt JH, et al. Blood pressure effects of the angiotensin II receptor blocker, losartan. Arch Intern Med. 1995;155: 405-411.

13. Weir MR, Elkins M, Liss C, Vrecenak AJ, Barr E, Edelman JM. Efficacy, tolerability, and quality of life of losartan, alone or with hydrochlorothiazide, versus nifedipine GITS in patients with essential hypertension. Clin Ther. 1996;18:411-428.

14. Oparil S, Dyke S, Harris F, et al. The efficacy and safety of valsartan compared with placebo in the treatment of patients with essential hypertension. Clin Ther. 1996;18:797-810.
15. Neutel J, Weber M, Pool J, et al. Valsartan, a new angiotensin II antagonist: antihypertensive effects over 24 hours. Clin Ther. 1997;19: 447-458.

16. Fogari R, Ambrosoli S, Corradi L, et al. 24-hour blood pressure control by once-daily administration of irbesartan assessed by ambulatory blood pressure monitoring. Irbesartan Multicenter Investigators' Group. J Hypertens. 1997;15:1511-1518.

17. Pool JL, Guthrie RM, Littlejohn TW 3rd, et al. Dose-related antihypertensive effects of irbesartan in patients with mild-to-moderate hypertension. Am J Hypertens. 1998;11:462-470.

18. Larochelle P, Flack JM, Marbury TC, Sareli P, Krieger EM, Reeves RA. Effects and tolerability of irbesartan versus enalapril in patients with severe hypertension. Am J Cardiol. 1997;80:1613-1615.

19. Mimran A, Ruilope L, Kerwin L, et al. A randomised, double-blind comparison of the angiotensin II receptor antagonist, irbesartan, with the full dose range of enalapril for the treatment of mild-to-moderate hypertension. J Hum Hypertens. 1998;12:203-208.

20. Stumpe KO, Haworth D, Hoglund C, et al. Comparison of the angiotensin II receptor antagonist irbesartan with atenolol for treatment of hypertension. Blood Press. 1998;7:31-37.

21. Lo MW, Goldberg MR, McCrea JB, Lu H, Furtek CI, Bjornsson TD. Pharmacokinetics of losartan, an antagonist II receptor antagonist and its active metabolite EXP3174 in humans. Clin Pharmacol Ther. 1995;58:641-649.

22. Vachharajani NN, Shyu WC, Chando TJ, Everett DW, Greene DS, Barbhaiya RH. Oral bioavailability and disposition characteristics of irbesartan, an angiotensin antagonist, in healthy volunteers. J Clin Pharmacol. 1998;38:702-207.

23. Waldmeier F, Flesch G, Müller P, et al. Pharmacokinetics, disposition and biotransformation of $\left[{ }^{14} \mathrm{C}\right]$ radiolabelled valsartan in health male volunteers after a single oral dose. Xenobiotica. 1997;27:59-71.

24. Criscione L, Bradley WA, Bühlmayer P, et al. Valsartan: preclinical profile of an antihypertensive angiotensin II antagonist. Cardiovasc Drug Rev. 1995;13:230-250.

25. Marino MR, Langenbacher K, Ford NF, Uderman HD. Pharmacokinetics and pharmacodynamics of irbesartan in healthy subjects. $J$ Clin Pharmacol. 1998;38:246-255.

26. Chando TJ, Everett DW, Kahle AD, et al. Biotransformation of irbesartan in man. Drug Metab Dispos. 1998;26:408-417.

27. Powell JR, Reeves RA, Marino MR, et al. A review of the new angiotensin II-receptor antagonist irbesartan. Cardiovasc Drug Rev. 1998;16:169-194.

28. Bourrié M, Meunier V, Berger Y, Fabre G. Role of cytochrome P-4502C9 in irbesartan oxidation by human liver microsomes. Drug Metab Dispos. 1999;27:288-296.

29. Marino M, Vachharajani N. Pharmacokinetics of irbesartan are not altered in special populations. J Cardiovasc Pharmacol. 2002;40:112-122.

30. Vachharajani NN, Shyu WC, Smith RA, Greene DS. The effects of age and gender on the pharmacokinetics of irbesartan. Br J Clin Pharmacol. 1998;46:611-613.

31. Sakarcan A, Tenney F, Wilson JT, et al. The pharmacokinetics of irbesartan in hypertensive children and adolescents. J Clin Pharmacol. 2001;41:742-749.

32. Sica DA, Marino MR, Hammett JL, Ferreira I, Gehr TW, Ford NF. The pharmacokinetics of irbesartan in renal failure and maintenance hemodialysis. Clin Pharmacol Ther. 1997;6:610-618.

33. Marino M, Langenbacher K, Raymond RH. Pharmacokinetics and pharmacodynamics of irbesartan in patient with hepatic cirrhosis. J Clin Pharmacol. 1998;4:347-356.

34. Kostis JB, Vachharajani N, Hadjilambris OW. The pharmacokinetics and pharmacodynamics of irbesartan in heart failure. J Clin Pharmacol. 2001;9:935-942.

35. Mangold B, Gielsdorf W, Marino MR. Irbesartan does not affect the steady-state pharmacodynamics and pharmacokinetics of warfarin. Eur J Clin Pharmacol. 1999;55:593-598.

36. Marino MR, Vachharajani NN, Hadjilambris OW. Irbesartan does not affect the pharmacokinetics of simvastatin in healthy subjects. J Clin Pharmacol. 2000;40:875-879. 
37. Marino MR, Langenbacher KM, Ford NF, et al. Effect of hydrochlorothiazide on the pharmacokinetics and pharmacodynamics of the angiotensin II blocker irbesartan. Clin Drug Investig. 1997;14:383-391.

38. Marino M, Hammett JL, Ferreira I. Lack of effect of nifedipine on the pharmacokinetics of irbesartan in healthy male subjects. J Clin Pharmacol. 1997;37:872.

39. Mazzolai L, Maillard M, Rossat J, Nussberger J, Brunner HR, Burnier M. Angiotensin II receptor blockade in normotensive subjects: a direct comparison of three AT1 receptor antagonists. Hypertension 1999;33:850-855.

40. Ribstein J, Picard A, Armagnac C, et al. Full antagonism of pressor response to exogenous angiotensin II (AII) by single-dose irbesartan in normotensive subjects. J Hypertens. 1997;15:S117.

41. Ribstein J, Sissmann J, Picard A, Bouroudian M, Mimran A. Effects of the angiotensin-II antagonist SR47436 (BMS 186295) on the pressor response to exogenous angiotensin-II and the renin-angiotensin system in sodium replete normal subjects. J Hypertens. 1994;12:131.

42. Marino MR, Langenbacher KM, Ford NF, et al. Pharmacokinetics and pharmacodynamics of irbesartan in patients with mild to moderate hypertension. J Cardiovasc Pharmacol Ther. 1999;4:67-75.

43. Pechère-Bertschi A, Nussberger J, Decosterd L, et al. Renal response to the angiotensin II receptor subtype 1 antagonist irbesartan versus enalapril in hypertensive patients. J Hypertens. 1998;16:385-393.

44. Schmitt F, Martinez F, Brillet G, et al. Acute renal effects of AT1-receptor blockade after exogenous angiotensin II infusion in healthy subjects. $J$ Cardiovasc Pharmacol. 1998;31:314-321.

45. Kassler-Taub K, Littlejohn T, Elliott W, Ruddy T, Adler E. Comparative efficacy of two angiotensin II receptor antagonists, irbesartan and losartan, in mild-to-moderate hypertension. Am J Hypertens. 1998;11 445-453.

46. Morales-Olivas FJ, Arístegui I, Estañ L, et al. The KARTAN study: a postmarketing assessment of Irbesartan in patients with hypertension. Clin Ther. 2004;26:232-344.

47. Chiou KR, Chen CH, Ding PY, et al. Randomized, double-blind comparison of irbesartan and enalapril for treatment of mild to moderate hypertension. Zhonghua Yi Xue Za Zhi (Taipei). 2000;63: 368-376.

48. Coca A, Calvo C, García-Puig J, et al. A multicenter, randomized, double-blind comparison of the efficacy and safety of irbesartan and enalapril in adults with mild to moderate essential hypertension, as assessed by ambulatory blood pressure monitoring: the MAPAVEL study. Clin Ther. 2002;24:126-138.

49. Lacourcière Y. A multicenter, randomized, double-blind study of the antihypertensive efficacy and tolerability of irbesartan in patients aged $\geq 65$ years with mild to moderate hypertension. Clin Ther. 2000;22:1213-1224.

50. Mancia G, Korlipara K, van Rossum P, Villa G, Silvert B. An ambulatory blood pressure monitoring study of the comparative antihypertensive efficacy of two angiotensin II receptor antagonists, irbesartan and valsartan. Blood Press Monit. 2002;7:135-142.

51. Neutel JM, Germino FW, Smith D. Comparison of monotherapy with irbesartan $150 \mathrm{mg}$ or amlodipine $5 \mathrm{mg}$ for treatment of mild-to-moderate hypertension. J Renin Angiotensin Aldosterone Syst. 2005;6:84-89.

52. Oparil S, Guthrie R, Lewin AJ, et al. An elective-titration study of the comparative effectiveness of two angiotensin II-receptor blockers, irbesartan and losartan. Clin Ther. 1998;20:398-409.

53. Rosenstock J, Rossi L, Lin CS, MacNeil D, Osbakken M. The effects of irbesartan added to hydrochlorothiazide for the treatment of hypertension in patients non-responsive to hydrochlorothiazide alone. J Clin Pharm Ther. 1998;23:433-440.

54. Howe P, Phillips P, Saini R, Kassler-Taub K. The antihypertensive efficacy of the combination of irbesartan and hydrochlorothiazide assessed by 24-hour ambulatory blood pressure monitoring. Irbesartan Multicenter Study Group. Clin Exp Hypertens. 1999;21:1373-1396.

55. Raskin P, Guthrie R, Flack J, Reeves R, Saini R. The long-term antihypertensive activity and tolerability of irbesartan with hydrochlorothiazide. J Hum Hypertens. 1999;13:683-687.
56. Bobrie G; I-ADD Study Investigators. I-ADD: assessment of efficacy and safety profile of irbesartan/amlodipine fixed-dose combination therapy compared with irbesartan monotherapy in hypertensive patients uncontrolled with irbesartan $150 \mathrm{mg}$ monotherapy: a multicenter, phase III, prospective, randomized, open-label with blinded-end point evaluation study. Clin Ther. 2012;34:1720-1734. e3.

57. Bobrie G; I-COMBINE Study Investigators. I-COMBINE study: assessment of efficacy and safety profile of irbesartan/amlodipine fixed-dose combination therapy compared with amlodipine monotherapy in hypertensive patients uncontrolled with amlodipine $5 \mathrm{mg}$ monotherapy: a multicenter, phase III, prospective, randomized, open-label with blinded-end point evaluation study. Clin Ther. 2012;34:1705-1719.

58. Bobrie G, Delonca J, Moulin C, Giacomino A, Postel-Vinay N, Asmar R. A home blood pressure monitoring study comparing the antihypertensive efficacy of two angiotensin II receptor antagonist fixed combinations. Am J Hypertens. 2005;18:1482-1488.

59. Neutel JM, Smith D. Ambulatory blood pressure comparison of the anti-hypertensive efficacy of fixed combinations of irbesartan/hydrochlorothiazide and losartan/hydrochlorothiazide in patients with mildto-moderate hypertension. J Int Med Res. 2005;33:620-631.

60. Hwang Y-S, Lu Y-H. Irbesartan monotherapy in systemic hypertension: an open-label, uncontrolled trial. Curr Ther Res. 2002;63:176-185.

61. Kawano Y, Sato Y, Yoshinaga K. A randomized trial of the effect of an angiotensin II receptor blocker SR47436 (irbesartan) on 24-hour blood pressure in patients with essential hypertension. Hypertens Res. 2008;31:1753-1763.

62. Coronel F, Cigarrán S, García-Mena M, Herrero JA, Calvo N, PérezFlores I. Irbesartan in hypertensive non-diabetic advanced chronic disease. Comparative study with ACEI. Nefrologia. 2008;28:56-60.

63. Oparil S, Williams D, Chrysant SG, Marbury TC, Neutel J. Comparative efficacy of olmesartan, losartan, valsartan, and irbesartan in the control of essential hypertension. J Clin Hypertens (Greenwich). 2001;3:283-318.

64. Cushman WC, Neutel JM, Saunders E, et al. Efficacy and safety of fixed combinations of irbesartan/hydrochlorothiazide in older vs younger patients with hypertension uncontrolled with monotherapy. Am J Geriatr Cardiol. 2008;17:27-36.

65. Al Balushi KA, Habib JQ, Al-Zakwani I. Comparative efficacy of irbesartan/hydrochlorothiazide and valsartan/hydrochlorothiazide combination in lowering blood pressure: a retrospective observational study in Oman. Med Princ Pract. 2013;22:265-269.

66. Chrysant SG, Neutel JM, Ferdinand KC; INCLUSIVE investigators. Irbesartan/hydrochlorothiazide for the treatment of isolated systolic hypertension: a subgroup analysis of the INCLUSIVE trial. J Natl Med Assoc. 2009;101:300-307.

67. Fogari R, Zoppi A, Mugellini A, et al. Efficacy and safety of two treatment combinations of hypertension in very elderly patients. Arch Gerontol Geriatr. 2009;48:401-405.

68. Franklin S, Lapuerta P, Cox D, Donovan M. Initial combination therapy with irbesartan/hydrochlorothiazide for hypertension: an analysis of the relationship between baseline blood pressure and the need for combination therapy. J Clin Hypertens (Greenwich). 2007;9:15-22.

69. Franklin SS, Neutel JM. Efficacy and safety of irbesartan/HCTZ in severe hypertension according to cardiometabolic factors. J Clin Hypertens (Greenwich). 2010;12:487-494.

70. Huang QF, Sheng CS, Li Y, Ma GS, Dai QY, Wang JG; INCENT Investigators. Efficacy and safety of a fixed combination of irbesartan/ hydrochlorothiazide in Chinese patients with moderate to severe hypertension. Drugs R D. 2013;13:109-117.

71. Kochar M, Guthrie R, Triscari J, Kassler-Taub K, Reeves RA. Matrix study of irbesartan with hydrochlorothiazide in mild-to-moderate hypertension. Am J Hypertens. 1999;12:797-805.

72. Meaney-Mendiolea E, Enrique Morales-Villegas, Mario Vélez-Tello de Meneses. Clinical effectiveness of irbesartan and irbesartan plus hydrochlorothiazide in women with mild to moderate essential hypertension. Clin Drug Investig. 2000;19:431-439. 
73. Neutel JM, Franklin SS, Oparil S, Bhaumik A, Ptaszynska A, Lapuerta P. Efficacy and safety of irbesartan/HCTZ combination therapy as initial treatment for rapid control of severe hypertension. J Clin Hypertens (Greenwich). 2006;8:850-859.

74. Ofili EO, Cable G, Neutel JM, Saunders E. Efficacy and safety of fixed combinations of irbesartan/hydrochlorothiazide in hypertensive women: the INCLUSIVE trial. $J$ Womens Health (Larchmt). 2008; 17:931-938.

75. Neutel JM, Saunders E, Bakris GL, et al. The efficacy and safety of low- and high- dose fixed combinations of irbesartan/hydrochlorothiazide in patients with uncontrolled systolic blood pressure on monotherapy: the INCLUSIVE trial. J Clin Hypertens (Greenwich). 2005;7: 578-586.

76. Neutel JM, Franklin SS, Lapuerta P, Bhaumik A, Ptaszynska A. A comparison of the efficacy and safety of irbesartan/HCTZ combination therapy with irbesartan and HCTZ monotherapy in the treatment of moderate hypertension. J Hum Hypertens. 2008;22:266-274.

77. Lewis EJ, Hunsicker LG, Clarke WR, et al. Renoprotective effects of the angiotensin-receptor antagonist irbesartan in patients with nephropathy due to type 2 diabetes. ACC Current Journal Review. 2002;11:26.

78. Parving HH, Lehnert H, Bröchner-Mortensen J, Gomis R, Andersen S, Arner P; Irbesartan in Patients with Type 2 Diabetes and Microalbuminuria Study Group. The effect of irbesartan on the development of diabetic nephropathy in patients with type 2 diabetes. $N$ Engl J Med. 2001;345:870-878.

79. de Alvaro F, Velasco O, Honorato J, Calvo C, Parrondo I; KORAL HT Investigators. Microalbuminuria in hypertensive patients: evaluation of one-year treatment with irbesartan. Kidney Int Suppl. 2005;93: S29-S34.

80. Lehnert H, Bramlage P, Pittrow D, Kirch W. Regression of microalbuminuria in type 2 diabetics after switch to irbesartan treatment: an observational study in 38,016 patients in primary care. Clin Drug Investig. 2004;24:217-225.

81. Sasso FC, Carbonara O, Persico M, et al. Irbesartan reduces the albumin excretion rate in microalbuminuric type 2 diabetic patients independently of hypertension: a randomized double-blind placebo-controlled crossover study. Diabetes Care. 2002;25:1909-1913.

82. Gaudio C, Ferri FM, Giovannini M, et al. Comparative effects of irbesartan versus amlodipine on left ventricular mass index in hypertensive patients with left ventricular hypertrophy. $J$ Cardiovasc Pharmacol. 2003;42:622-628.

83. Malmqvist K, Kahan T, Edner M, Bergfeldt L. Comparison of actions of irbesartan versus atenolol on cardiac repolarization in hypertensive left ventricular hypertrophy: results from the Swedish Irbesartan Left Ventricular Hypertrophy Investigation Versus Atenolol (SILVHIA). Am J Cardiol. 2002;90:1107-1112.

84. Malmqvist K, Kahan T, Edner M, et al. Regression of left ventricular hypertrophy in human hypertension with irbesartan. J Hypertens. 2001;19:1167-1176.

85. Müller-Brunotte R, Edner M, Malmqvist K, Kahan T. Irbesartan and atenolol improve diastolic function in patients with hypertensive left ventricular hypertrophy. $J$ Hypertens. 2005;23:633-640.

86. Annemans L, Demarteau N, Hu S, et al. An Asian regional analysis of cost-effectiveness of early irbesartan treatment versus conventional antihypertensive, late amlodipine, and late irbesartan treatments in patients with type 2 diabetes, hypertension, and nephropathy. Value Health. 2008;11:354-364.

Vascular Health and Risk Management

\section{Publish your work in this journal}

Vascular Health and Risk Management is an international, peerreviewed journal of therapeutics and risk management, focusing on concise rapid reporting of clinical studies on the processes involved in the maintenance of vascular health; the monitoring, prevention and treatment of vascular disease and its sequelae; and the involvement of
87. Coyle D, Rodby R, Soroka S, et al. Cost-effectiveness of irbesartan $300 \mathrm{mg}$ given early versus late in patients with hypertension and a history of type 2 diabetes and renal disease: a Canadian perspective. Clin Ther. 2007;29:1508-1523.

88. Coyle D, Rodby RA. Economic evaluation of the use of irbesartan and amlodipine in the treatment of diabetic nephropathy in patients with hypertension in Canada. Can J Cardiol. 2004;20:71-79.

89. Ekman M, Bienfait-Beuzon C, Jackson J. Cost-effectiveness of irbesartan/hydrochlorothiazide in patients with hypertension: an economic evaluation for Sweden. J Hum Hypertens. 2008;22:845-855.

90. Maniadakis N, Ekman M, Fragoulakis V, Papagiannopoulou V, Yfantopoulos J. Economic evaluation of irbesartan in combination with hydrochlorothiazide in the treatment of hypertension in Greece. Eur J Health Econ. 2011;12:253-261.

91. Palmer AJ, Annemans L, Roze S, et al. Cost-effectiveness of irbesartan in patients with type 2 diabetes, hypertension and nephropathy: the Italian perspective. Pharmacoeconomics. 2005;1:43-57.

92. Palmer AJ, Annemans L, Roze S, et al. Cost-effectiveness of early irbesartan treatment versus control (standard antihypertensive medications excluding ACE inhibitors, other angiotensin-2 receptor antagonists, and dihydropyridine calcium channel blockers) or late irbesartan treatment in patients with type 2 diabetes, hypertension, and renal disease. Diabetes Care. 2004;27:1897-1903.

93. Palmer AJ, Annemans L, Roze S, et al. Irbesartan is projected to be cost and life saving in a Spanish setting for treatment of patients with type 2 diabetes, hypertension, and microalbuminuria. Kidney Int Suppl. 2005;67:S52-S54.

94. Rodby RA, Chiou CF, Borenstein J, et al. The cost-effectiveness of irbesartan in the treatment of hypertensive patients with type 2 diabetic nephropathy. Clin Ther. 2003;25:2102-2119.

95. Palmer AJ, Annemans L, Roze S, Lamotte M, Rodby RA, Bilous RW. An economic evaluation of the Irbesartan in Diabetic Nephropathy Trial (IDNT) in a UK setting. J Hum Hypertens. 2004;18: 733-738.

96. Palmer AJ, Annemans L, Roze S, Lamotte M, Rodby RA, Cordonnier DJ. An economic evaluation of irbesartan in the treatment of patients with type 2 diabetes, hypertension and nephropathy: costeffectiveness of Irbesartan in Diabetic Nephropathy Trial (IDNT) in the Belgian and French settings. Nephrol Dial Transplant. 2003;18: 2059-2066.

97. Palmer AJ, Roze S, Valentine WJ, et al. Health economic implications of irbesartan plus conventional antihypertensive medications versus conventional blood pressure control alone in patients with type 2 diabetes, hypertension, and renal disease in Switzerland. Swiss Med Wkly. 2006;136:346-352.

98. Palmer AJ, Valentine WJ, Ray JA. Irbesartan treatment of patients with type 2 diabetes, hypertension and renal disease: a UK health economics analysis. Int J Clin Pract. 2007;61:1626-1633.

99. Palmer AJ, Valentine WJ, Ray JA, Roze S, Muszbek N. Health economic implications of irbesartan treatment versus standard blood pressure control in patients with type 2 diabetes, hypertension and renal disease: a Hungarian analysis. Eur J Health Econ. 2007;8: 161-168.

100. Palmer AJ, Valentine WJ, Tucker DM, et al. A French cost-consequence analysis of the renoprotective benefits of irbesartan in patients with type 2 diabetes and hypertension. Curr Med Res Opin. 2006;22:2095-2100.

\section{Dovepress}

metabolic disorders, particularly diabetes. This journal is indexed on PubMed Central and MedLine. The manuscript management system is completely online and includes a very quick and fair peer-review system, which is all easy to use. Visit http://www.dovepress.com/ testimonials.php to read real quotes from published authors. 